\title{
Drosophila Amyloid Precursor Protein-Like Is Required for Long-Term Memory
}

\author{
Valérie Goguel, ${ }^{1}$ Anne-Laure Belair, ${ }^{1}$ Derya Ayaz, ${ }^{2,3}$ Aurélie Lampin-Saint-Amaux, ${ }^{1}$ Niki Scaplehorn, ${ }^{1}$ \\ Bassem A. Hassan, ${ }^{2,3}$ and Thomas Preat ${ }^{1}$ \\ ${ }^{1}$ Genes and Dynamics of Memory Systems, Neurobiology Unit, Centre National de la Recherche Scientifique, Ecole Supérieure de Physique et de Chimie \\ Industrielles, 75005 Paris, France, ${ }^{2}$ Laboratory of Neurogenetics, Department of Molecular and Developmental Genetics, Vlaams Instituut voor \\ Biotechnologie, 3000 Leuven, Belgium, and ${ }^{3}$ Center for Human Genetics and Doctoral Program in Molecular and Developmental Genetics, Katholieke \\ Universiteit Leuven School of Medicine, 3000 Leuven, Belgium
}

The amyloid precursor protein (APP) plays an important role in Alzheimer's disease (AD), a progressive neurodegenerative pathology that first manifests as a decline of memory. While the main hypothesis for AD pathology centers on the proteolytic processing of APP, very little is known about the physiological function of the APP protein in the adult brain. Likewise, whether APP loss of function contributes to AD remains unclear. Drosophila has been used extensively as a model organism to study neuronal function and pathology. In addition, many of the molecular mechanisms underlying memory are thought to be conserved from flies to mammals, prompting us to study the function of APPL, the fly APP ortholog, during associative memory. It was previously shown that APPL expression is highly enriched in the mushroom bodies (MBs), a specialized brain structure involved in olfactory memory. We analyzed memory in flies in which APPL expression has been silenced specifically and transiently in the adult MBs. Our results show that in adult flies, APPL is not required for learning but is specifically involved in long-term memory, a long lasting memory whose formation requires de novo protein synthesis and is thought to require synaptic structural plasticity. These data support the hypothesis that disruption of normal APP function may contribute to early AD cognitive impairment.

\section{Introduction}

Alzheimer's disease $(\mathrm{AD})$ is characterized by the accumulation of neurofibrillary tangles, the loss of synapses and neurons in specific areas of the brain, and the formation of amyloid plaques. These $\beta$-amyloid deposits result from the aggregation of $\mathrm{A} \beta$ peptides, which are generated through proteolytic processing of the integral membrane protein amyloid precursor protein (APP) (Selkoe, 2001; Annaert and De Strooper, 2002). The amyloid hypothesis, which postulates that $\mathrm{A} \beta$ deposits are the primary influence driving AD pathogenesis (Hardy and Selkoe, 2002), has been the basis for intensive work, and age-related $\mathrm{A} \beta$ toxicity has been well documented in several organisms (LaFerla et al., 1995; McKee et al., 1998; Finelli et al., 2004; Iijima et al., 2004). However, we still have little idea of the initial events leading to memory decline in $\mathrm{AD}$. There is no simple correlation between the density of amyloid plaques and the clinical progression of the

Received June 7, 2010; revised 0ct. 15, 2010; accepted Nov. 8, 2010.

This work was supported by grants from the Agence Nationale pour la Recherche, the Fondation pour la Recherche sur le Cerveau, and the Fondation pour la Recherche Médicale (T.P.) as well as Vlaams Instituut voor Biotechnologie, Concerted Research Action (GOA), and Methusalem funding from Katholieke Universiteit Leuven (B.A.H). A.L.B. was supported by the Région Ile-de-France. N.S. was supported by the Human Frontier Science Program and the European Molecular Biology Organization. We thank J. M. Dura and B. De Stooper for critical reading of this manuscript, B. De Stooper for the kind gift of anti-APP antibodies, and members of our laboratory for fruitful discussions. We also thank J. Séjourné and P. Tchénio for help with confocal images analysis.

Correspondence should be addressed to Dr. Thomas Preat, Genes and Dynamics of Memory Systems, Neurobiology Unit, Centre National de la Recherche Scientifique, Ecole Supérieure de Physique et de Chimie Industrielles, 10 Rue Vauquelin, 75005 Paris, France. E-mail: thomas.preat@espci.fr.

DOI:10.1523/JNEUROSCI.2896-10.2011

Copyright $\odot 2011$ the authors $\quad 0270-6474 / 11 / 311032-06 \$ 15.00 / 0$ disease (Braak and Braak, 1991), and brains of nondemented elderly people can show substantial levels of $\mathrm{A} \beta$ plaques (Knopman et al., 2003). Furthermore, APP appears to be involved in physiological functions such as cell adhesion, neurite outgrowth, synaptogenesis, and G protein-coupled receptor signaling (Turner et al., 2003; Zheng and Koo, 2006).

Many human neurodegenerative diseases can be modeled in Drosophila melanogaster (Bilen and Bonini, 2005), whose genome contains homologs of $\sim 70 \%$ of human disease-related genes (Fortini et al., 2000; Reiter et al., 2001). APP belongs to a conserved gene family that includes the mammalian APLP1 and APLP2 genes and a single Drosophila homolog called Appl (Luo et al., 1990). APPL is specifically expressed in neurons during all stages of development (Martin-Morris and White, 1990) and has been implicated in axonal transport (Torroja et al., 1999a; Gunawardena and Goldstein, 2001), neuronal development (Li et al., 2004; Merdes et al., 2004), synaptic bouton formation (Torroja et al., 1999b; Ashley et al., 2005), and the neuronal response to traumatic brain injury (Leyssen et al., 2005).

Although the $\mathrm{A} \beta$ sequences are not conserved in APPL, it has been shown that expression of human $A \beta$ results in many of the features observed in the mouse model, such as age-dependent neurodegeneration and behavioral defects (Finelli et al., 2004; Greeve et al., 2004; Iijima et al., 2004; Crowther et al., 2005; Zhao et al., 2010), indicating that Drosophila constitutes a relevant model to study the molecular basis of AD pathogenesis.

In contrast to studies that directly model $\mathrm{AD}$ pathology by ectopic expression of $\mathrm{A} \beta$, we investigated the physiological func- 
tion of APPL in the adult brain by assessing its role in associative memory. For that purpose, we used the Gal4-Switch/RNA interference (RNAi) system (Brand and Perrimon, 1993; Piccin et al., 2001; Roman and Davis, 2001) to decrease APPL expression in the adult mushroom bodies (MBs), the olfactory memory center (Heisenberg, 1998). Our results show that APPL is specifically required for long-term memory (LTM) formation.

\section{Materials and Methods}

Flies. Drosophila melanogaster wild-type strain Canton Special (CS) and mutant flies were raised on standard medium at $18^{\circ} \mathrm{C}$ with $60 \%$ humidity in a $12 \mathrm{~h}$ light/dark cycle. All strains used for memory experiments were outcrossed to the CS background. The Appl-42673 RNAi line (42673) was obtained from the Vienna Drosophila RNAi Center (Vienna, Austria). The Appl-G3 RNAi was constructed according to Kalidas and Smith (2002) and targets nucleotides 2119-2737 of the transcript (FlyBase ID FBtr0070109). To induce RNAi expression, the GeneSwitch system was used as described by Mao et al. (2004). Flies were kept on RU486containing medium (RU) (SPI-Bio) for $2 \mathrm{~d}$ before conditioning and also for $24 \mathrm{~h}$ after (when memory was tested at $24 \mathrm{~h}$ ). A stock solution ( $10 \mathrm{~mm}$ in $80 \%$ ethanol) was mixed into molten food at $65^{\circ} \mathrm{C}$ to a final concentration of $200 \mu \mathrm{M}$.

Behavior analyses. Flies were trained with classical olfactory aversive conditioning protocols as described by Pascual and Preat (2001). Training and testing were performed at $25^{\circ} \mathrm{C}$ with $80 \%$ humidity. Conditioning was performed on samples of 25-35 flies aged between 2 and $3 \mathrm{~d}$ with 3-octanol (>95\% purity; Fluka 74878, Sigma-Aldrich) and 4-methylcyclohexanol (99\% purity; Fluka 66360, Sigma-Aldrich) at $0.360 \mathrm{~mm}$ and $0.325 \mathrm{~mm}$, respectively. Odors were diluted in paraffin oil (VWR International, SigmaAldrich). Memory tests were performed with a T-maze apparatus (Tully and Quinn, 1985). Flies could choose for 1 min between two arms, each delivering a distinct odor. An index was calculated as the difference between the numbers of flies in each arm divided by the sum of flies in both arms. A performance index (PI) results from the average of two reciprocal experiments. For odor avoidance tests after electric shock and response to electric shock, flies were treated as described by Pascual and Preat (2001).

Statistical analysis. Quantification measurements were analyzed using Student's $t$ tests. For behavior experiments, scores resulting from all genotypes, excluding the CS, were analyzed using one-way ANOVA followed, if significant at $p<0.05$, by the Newman-Keuls multiple comparisons test.

Quantitative PCR analysis. Flies expressing Appl-RNAi under the control of the elav-Gal4 driver were raised at $25^{\circ} \mathrm{C}$. Total RNA was extracted from 25-30 fly heads with the RNeasy Plant Mini Kit (Qiagen) and reverse transcribed with oligo $(\mathrm{dT})_{20}$ primers using the SuperScript III First-Stand kit (Invitrogen) according to the manufacturer's instructions. We compared the level of Appl cDNA to that of the $\alpha$-Tub84B (CG1913) cDNA, which was used as a reference. Amplification was performed using a LightCycler 480 (Roche) in conjunction with the SYBR Green I Master (Roche). Reactions were carried out in triplicate for two dilutions of each cDNA, and three independent experiments were performed. The specificity and size of amplification products were assessed by melting curve analysis and agarose gel electrophoresis, respectively. Expression relative to $t u b$ is expressed as a ratio $\left(2^{-\Delta \Delta C \mathrm{P}}\right.$, where $\mathrm{Cp}$ is crossing point). A ratio of 1 represents the relative expression observed in control flies.

Immunohistochemistry. Freshly dissected brains of adult flies were processed for immunochemistry as described previously ( $\mathrm{Wu}$ and Luo, 2006). Primary antibodies were mouse anti-FasII at 1:400 (1D4; Developmental Studies Hybridoma Bank, University of Iowa, Iowa City, IA) and rabbit anti-APP (Annaert et al., 1999), an antibody that also reacts with the fly APPL protein, at 1:15,000. Secondary antibodies were Alexa Fluor 488-conjugated anti-rabbit at 1:400 (Invitrogen) and Alexa Fluor 594-conjugated anti-mouse at 1:400 (Invitrogen). Confocal stacks were acquired on whole mounted brains for Alexa Fluor 488 and Alexa Fluor 594 fluorophores in sequential line mode on an A1-Nikon confocal microscope. Using FasII labeled images, substacks were extracted that contained all the sections in which appeared the $\alpha$ or $\beta$ lobes. APPL was then quantified with the ImageJ image processing program. After a maximal projection, a region of interest (ROI) corresponding to $\beta$ lobes was determined from FasII labeled projected image, and the FasII and APP signals were measured in this ROI. The ratio of the two values was used to quantify the relative APPL expression.

\section{Results}

Aversive olfactory memory studies can rely on classical conditioning of an odor avoidance response. In this paradigm, groups of flies are successively exposed to two distinct odors, only one of which is accompanied by electric shocks (Pascual and Preat, 2001). Memory scores are determined by placing the flies in the center of a T-maze where they are simultaneously exposed to the two odors during $1 \mathrm{~min}$ (Tully and Quinn, 1985; see Materials and Methods).

To knock down expression of the APPL gene, we took advantage of RNAi-mediated silencing. The efficiency of two distinct RNAi constructs targeting APPL (42673 and G3; see Materials and Methods) was analyzed using the elav-Gal4 driver (elav) that drives pan-neuronal expression of UAS-regulated transgenes (Brand and Perrimon, 1993). APPL expression in fly heads was quantified by real-time PCR. The data show a sharp decrease in Appl mRNA levels in elav/+;42673/+ as well as in elav/+;G3/+ flies compared with those observed in elav/ + control flies $(13 \%$ and 25\%, respectively) (Fig. $1 \mathrm{~A}$ ), establishing that both RNAi constructs efficiently target APPL mRNA.

The MBs constitute a prominent bilateral structure of the insect brain comprising $\sim 2000$ neurons per brain hemisphere (Aso et al., 2009). Three categories of these neurons extend their axons through the peduncle to give rise to the $\alpha / \beta, \alpha^{\prime} / \beta^{\prime}$, and $\gamma$ lobes, respectively (Crittenden et al., 1998). To study the effect of APPL silencing on memory, we used the MB247 enhancer that drives expression in the $\alpha / \beta$ and $\gamma$ neurons (Schwaerzel et al., 2002). Although Appl deletion does not affect the gross structure of the MBs (Luo et al., 1992), it leads to subtle abnormal morphology of the MB lobes (Li et al., 2004). Thus, to avoid potential developmental defects that could affect memory performance, we decided to restrict Appl RNAi expression to adulthood using the conditional GeneSwitch activator (Roman et al., 2001) under the control of MB247 sequences (MB-Sw) (Mao et al., 2004). We first addressed the validity of the Switch system by analyzing APPL protein expression in whole mount brains from MB-Sw/G3 flies fed or not fed with the RU inducible drug. As described previously in wild-type flies (Torroja et al., 1996), the $\alpha / \beta$ and $\gamma$ lobes of the adult MB neuropils were stained in the MB-Sw/G3 flies that were not fed with RU (Fig. $1 B$ ). MBs staining was lower in the MB-Sw/G3 flies fed with RU (Fig. 1B). Appl $l^{d}$-null mutant flies (Luo et al., 1992) did not exhibit any staining of the MBs, while a large amount of cell bodies displayed nonspecific staining (data not shown). Quantification of the signals present in the $\beta$ lobes revealed a significant 39\% decrease in APPL levels for flies fed with RU compared with control flies (Fig. 1C), showing that APPL expression is silenced when the Switch driver is induced.

We next verified that Appl RNAi-expressing flies perceived normally the stimuli used for conditioning. Their response to each odor after electric shock exposure was not impaired, and neither was their ability to escape electric shocks (Fig. 2). Luo et al. (1992) previously reported that $A p p l^{d}$-null mutant flies did not react normally to electric shock. To try to understand the origin of this defect, we analyzed the effect of Appl RNAi ubiquitous expression in the adult using the da-Switch driver (Tricoire et al., 2009), as well as that of its constitutive expression in the MBs using the MB247-Gal4 driver. In both cases, resulting flies reacted 
normally to shocks (data not shown). These results suggest that the defect described by Luo et al. (1992) may result either from the complete lack of APPL expression in the adult, or from a developmental defect other than that of the MBs.

Depending on the training protocol, different types of memory can be measured (Tully et al., 1994). Short-term memory (STM), middle-term memory (MTM), and anesthesia-resistant memory (ARM) are formed after one cycle of training. Both STM and MTM are labile memory phases sensitive to cold shock anesthesia; STM lasts for an hour while MTM lasts for a few hours. In contrast, ARM is a consolidated form of memory that can last for days (Chabaud et al., 2009). When tested $2 \mathrm{~h}$ after a single conditioning cycle, we did not observe significant differences in memory scores for the flies expressing Appl RNAi compared with the controls, showing that neither learning, STM, nor $2 \mathrm{~h}$ ARM are sensitive to Appl RNAi expression (Fig. 3A). To further analyze ARM, consolidated memory was assessed using a reinforced training protocol. After massed conditioning comprising five consecutive repeated cycles of training, scores at $24 \mathrm{~h}$ were not significantly different when either RNAi construct was expressed (Fig. 3B), showing that ARM is not affected.

LTM is also a form of consolidated memory, but unlike ARM its formation is sensitive to an inhibitor of cytoplasmic protein synthesis, indicating that it requires de novo protein synthesis (Tully et al., 1994). LTM is generated after spaced conditioning consisting of repeated training sessions, each separated by a 15 min rest period. Analysis of LTM after five spaced conditioning cycles revealed that flies expressing either 42673 or G3 Appl RNAi construct displayed a score significantly lower than their respective controls (Fig. 3C). When flies were not fed with RU, all genotypes exhibited normal performance at $24 \mathrm{~h}$ after spaced conditioning (Fig. 3D), showing that the observed decrease in LTM is RU specific and is thus caused by the Gal4-Switchdependent induction of $A p p l$ RNAi. Altogether, the data establish that transient expression of RNAi directed against Appl in the adult MBs impairs LTM, whereas neither STM nor ARM is affected. We conclude that APPL expression in the MBs of adult flies is specifically required for LTM. Moreover, as immunohistochemistry experiments indicate that MB-Sw/Appl-RNAi flies are not amorphous for APPL expression in the MBs, it appears that a partial knock-down of APPL expression is sufficient to impair LTM.

We next aimed to analyze whether human APP could rescue the LTM defect observed in MB-Sw/APPL-RNAi flies. However, we could not perform this experiment, as flies expressing human APP (Gunawardena and Goldstein, 2001) in the adult MBs exhibited an LTM defect (Fig. 4).

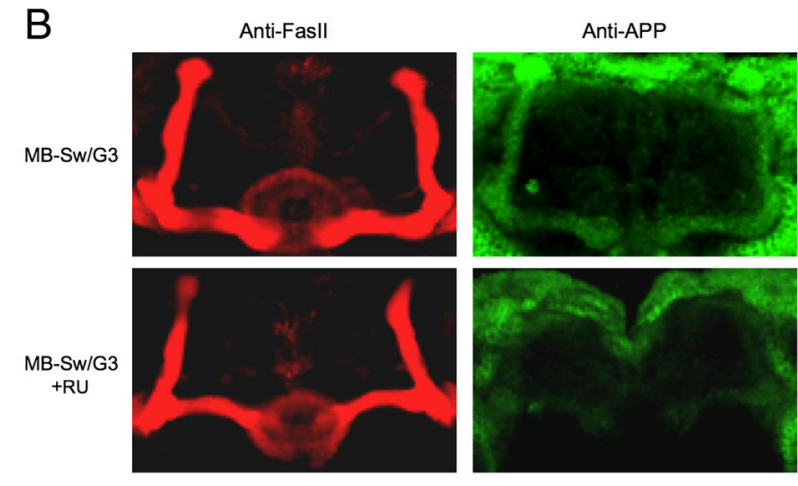

Figure 1. Appl RNA is targeted by RNAi constructs. $\boldsymbol{A}$, Quantitative PCR analysis. Total RNA was extracted from elav/+; $42673 /+$, elav/ +;G3/+, and control fly heads, respectively, and further reverse transcribed with oligo(dT) primers. Resulting DNA was quantified using tubulin (Tub) expression as a reference. Results are shown as ratios relative to the values observed for without or with (+RU) RU were incubated with anti-Fasll antibodies to label the $\alpha / \beta$ and $\gamma$ neurons of the MBs (red) and anti-APP antibodies (green). C, APPL relative quantification in the $\beta$ lobes. Results are shown as APP/Fasll signal ratios ( $t$ test,
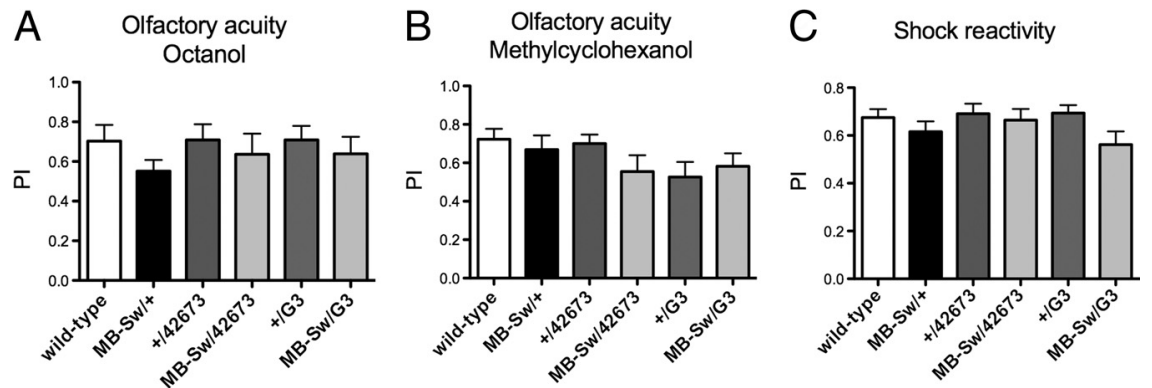

Figure 2. Neither olfactory acuity nor electric shock reactivity are impaired in Appl-RNAi flies. $\boldsymbol{A}-\boldsymbol{C}$, Flies were fed with RU for $8 \mathrm{~h}$ before testing olfactory acuity and shock reactivity. $\boldsymbol{A}, \boldsymbol{B}$, Olfactory acuity for octanol (ANOVA, $p=0.6141, n \geq 8)(\boldsymbol{A})$ and olfactory acuity for methylcyclohexanol (ANOVA, $p=0.3769, n \geq 10)(B)$. C, Shock sensitivity. (ANOVA, $p=0.5616, n \geq 12$ ). A performance index $(\mathrm{PI})$ was calculated as for memory tests. Bars, Mean \pm SEM.

\section{Discussion}

We took advantage of inducible RNAi expression to study the function of endogenous amyloid precursor protein-like in the Drosophila olfactory memory center. Specifically reducing APPL expression in the adult MBs led to LTM disruption, showing that the observed memory defect is not caused by a subtle alteration in brain development. Furthermore, although we did not search for amyloid deposits in knock-down flies, it seems unlikely that decreasing APPL expression for $2 \mathrm{~d}$ may result in their production. Rather, memory impairment is most likely caused by the loss of APPL function in young flies.

Luo et al. (1992) previously reported the construction and analysis of flies lacking the APPL gene $\left(A p p l^{d}\right)$. They observed significantly lower STM scores after one cycle of aversive conditioning but could not conclude that Appl-null mutation led to a memory defect, because $A p p l^{d}$ flies did not react normally to electric shock. In our study, flies showed normal reaction to electric shock, odor avoidance, and STM. A possible explanation is that previously observed behavioral deficits may have been caused by a mild defect in brain development or by the complete 
A

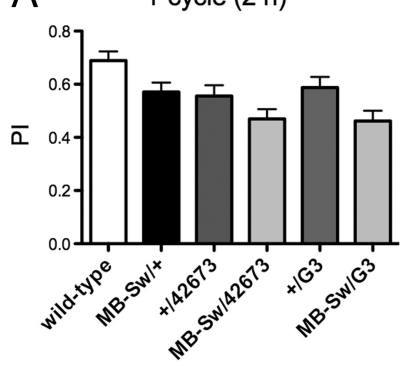

C

5-spaced cycles $(24 \mathrm{~h})$

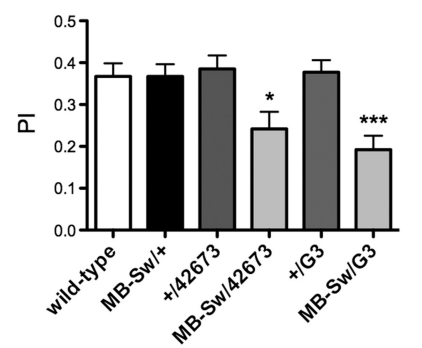

B 5-massed cycles $(24 \mathrm{~h})$

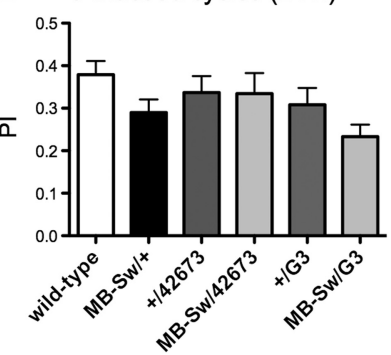

D
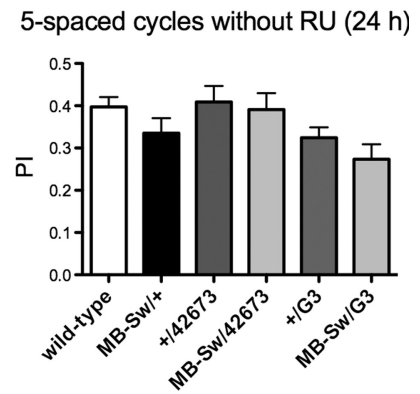

Figure 3. LTM is specifically affected in Appl-RNAi flies. $\boldsymbol{A}-\boldsymbol{C}$, Flies were fed with RU for $48 \mathrm{~h}$ before conditioning and, in $\boldsymbol{B}$ and $\boldsymbol{C}$, also for $24 \mathrm{~h}$ before testing. $\boldsymbol{A}$, STM is not affected. Flies were submitted to one cycle training and tested $2 \mathrm{~h}$ later (ANOVA, $p=$ $0.0514, n \geq 25$ ). $\boldsymbol{B}$, ARM is not affected. Flies were submitted to five massed conditioning cycles and memory was assessed $24 \mathrm{~h}$ later. (ANOVA, $p=0.2823, n \geq 25$ ). C, LTM is affected. Flies were trained with five spaced conditioning cycles and tested $24 \mathrm{~h}$ later (ANOVA, $p<0.0001, n \geq 32$; Newman-Keuls post-tests: MB-Sw/G3 vs $+/ \mathrm{G} 3, \mathrm{q}=$ 5.623; MB-Sw/G3 vs MB-Sw/+, $q=5.647 ; M B-S w / 42673$ vs $+/ 42673, p=4.164 ;$ MB-Sw/42673 vs MB-Sw/+, $q=3.943 ;{ }^{*} p<0.05,{ }^{* * *} p<0.001$.). $D$, In the absence of RU, LTM is not affected. Flies were raised on regular medium, submitted to a five-spaced cycle conditioning, and tested $24 \mathrm{~h}$ later (ANOVA, $p=0.0446, n \geq 25$; the NewmanKeuls post-test is significant for the MB-Sw/G3 vs +/42673 pair). Bars, Mean \pm SEM. $\mathrm{PI}$, Performance index.

\section{5-spaced cycles $(24 \mathrm{~h})$}

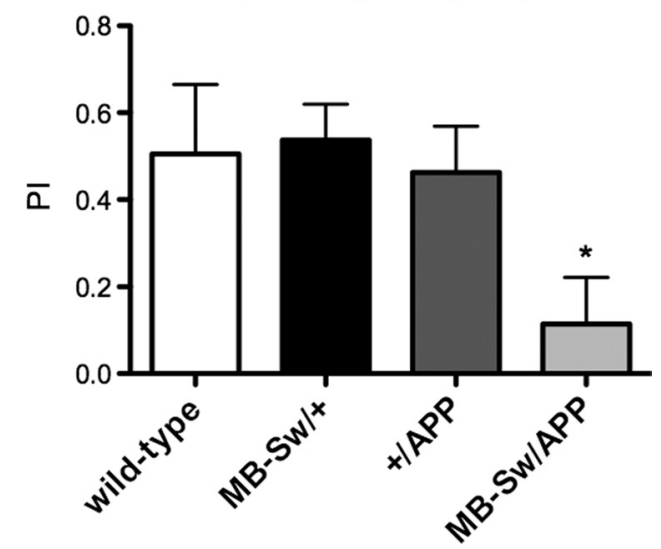

Figure 4. LTM is impaired in flies expressing human APP in the MBs. Flies were fed with $\mathrm{RU}$ for $48 \mathrm{~h}$ before spaced conditioning and for $24 \mathrm{~h}$ before performing memory tests. Performance indexes (PIs) calculated for female flies reveal that flies expressing APP in the adult MBs (MB-Sw/APP) display a memory score significantly different from that observed for the controls MB-SW/ + and $+/ \mathrm{APP}$, respectively (ANOVA, ${ }^{*} p=0.0200, n=6$ ). Bars, mean \pm SEM.

lack of APPL in the adult or both. Because APPL is highly expressed in the central complex (Torroja et al., 1996), the major Drosophila brain structure controlling locomotor behavior (Strauss and Heisenberg, 1993), it is possible that the

complete lack of APPL in this structure could lead to motor defects.

In mice, several loss-of-function analyses have suggested that APP might be involved in learning and memory. These studies have relied upon knock-out (KO) (Dawson et al., 1999; Phinney et al., 1999; Senechal et al., 2008) or knock-in techniques (Ring et al., 2007) or injection of anti-APP antibodies (Taylor et al., 2008) or antisense oligonucleotides (Senechal et al., 2007). Single APP KO leads to relatively mild behavioral defects, probably caused by functional redundancy (Muller et al., 1994; Zheng et al., 1995), while the adult APP ${ }^{-1-}$ APLP1 ${ }^{-1-}$ APLP $^{-1-}$ triple KO cannot be analyzed because of early postnatal lethality (Herms et al., 2004). APP-null mice display neuroanatomical abnormalities and reduced brain weight, suggesting that APP plays a role in development and somatic growth. It is thus difficult to determine in $\mathrm{KO}$ studies the relative contributions of defects caused by a role in the adult brain versus those caused by a requirement during the development and maintenance of neuronal networks. Also, injection experiments should be interpreted with caution, as antibodies might not be specific for a single APP species, and in addition, interaction of APP with an antibody might activate intracellular APP-mediated signaling events (Mbebi et al., 2005). Not only does Drosophila present the advantage of a single APP-encoding gene, but the genetic tools available in this organism allow specific silencing in a restricted part of the adult brain.

It has been proposed that $\mathrm{AD}$ physiopathology might in part be caused by loss of normal APP function, in particular during the early stages of the disease characterized by memory impairment (Neve et al., 2000). APP processing by the amyloid pathway precludes its cleavage by $\alpha$-secretase, thus leading to a decrease in the production of secreted $\operatorname{APP} \alpha(\operatorname{sAPP} \alpha)$, a neurotrophic and neuroprotective peptide (Turner et al., 2003). Indeed, several studies have shown that $\operatorname{sAPP} \alpha$ levels are decreased in both familial and sporadic $\mathrm{AD}$, while low levels have been correlated with poor memory performance in humans (Almkvist et al., 1997; Sennvik et al., 2000). It was thus suggested that decreased amounts of sAPP $\alpha$ in AD brain contributed to the memory deficit characterizing $\mathrm{AD}$, independently of $\mathrm{A} \beta$ toxicity. Consistent with these observations, analyses in rodents have shown a role for sAPP $\alpha$ in spatial memory (Bour et al., 2004; Ring et al., 2007; Taylor et al., 2008). Our data establish that in the fly a memory deficit is caused by loss of APPL function independently of the toxicity of the amyloid pathway, thus giving further support to the hypothesis that loss of function might contribute to early $\mathrm{AD}$ cognitive decline.

The first symptom of $\mathrm{AD}$ is a disability to encode new memories while old declarative memory remains unaffected (Forstl and Kurz, 1999). We report here that APPL loss of function in the fly affects LTM formation, whereas learning, STM, and ARM remain unaffected. Although it is not straightforward to compare complex behavioral deficits occurring in $\mathrm{AD}$ patients to those of invertebrates, at first glance these observations could appear contradictory. In Drosophila, LTM is the only memory form that relies on de novo protein synthesis and is therefore likely to involve long-lasting changes in synaptic plasticity. This leads us to hypothesize that APPL dysfunction causes a failure of synaptic plasticity such as that thought to underlie the earliest cognitive features of $\mathrm{AD}$ (Selkoe, 2002), namely an impairment in acquiring new information. It is possible that initial AD symptoms might be generated by APP loss of function, while further cognitive decline might result from progressive loss of synapses and neurons 
due, at least in part, to an additional toxic pathogenic mechanism such as $A \beta$ accumulation. In the future, the power of genetic manipulation in the fly, together with behavioral studies, should allow us to unravel APPL function in memory.

\section{References}

Almkvist O, Basun H, Wagner SL, Rowe BA, Wahlund LO, Lannfelt L (1997) Cerebrospinal fluid levels of alpha-secretase-cleaved soluble amyloid precursor protein mirror cognition in a Swedish family with Alzheimer disease and a gene mutation. Arch Neurol 54:641-644.

Annaert W, De Strooper B (2002) A cell biological perspective on Alzheimer's disease. Annu Rev Cell Dev Biol 18:25-51.

Annaert WG, Levesque L, Craessaerts K, Dierinck I, Snellings G, Westaway D, George-Hyslop PS, Cordell B, Fraser P, De Strooper B (1999) Presenilin 1 controls gamma-secretase processing of amyloid precursor protein in pre-Golgi compartments of hippocampal neurons. J Cell Biol 147:277-294.

Ashley J, Packard M, Ataman B, Budnik V (2005) Fasciclin II signals new synapse formation through amyloid precursor protein and the scaffolding protein dX11/Mint. J Neurosci 25:5943-5955.

Aso Y, Grübel K, Busch S, Friedrich AB, Siwanowicz I, Tanimoto H (2009) The mushroom body of adult Drosophila characterized by GAL4 drivers. J Neurogenet 23:156-172.

Bilen J, Bonini NM (2005) Drosophila as a model for human neurodegenerative disease. Annu Rev Genet 39:153-171.

Bour A, Little S, Dodart JC, Kelche C, Mathis C (2004) A secreted form of the beta-amyloid precursor protein (sAPP695) improves spatial recognition memory in OF1 mice. Neurobiol Learn Mem 81:27-38.

Braak H, Braak E (1991) Neuropathological stageing of Alzheimer-related changes. Acta Neuropathol 82:239-259.

Brand AH, Perrimon N (1993) Targeted gene expression as a means of altering cell fates and generating dominant phenotypes. Development 118:401-415.

Chabaud MA, Isabel G, Kaiser L, Preat T (2009) Social facilitation of longlasting memory retrieval in Drosophila. Curr Biol 19:1654-1659.

Crittenden JR, Skoulakis EM, Han KA, Kalderon D, Davis RL (1998) Tripartite mushroom body architecture revealed by antigenic markers. Learn Mem 5:38-51.

Crowther DC, Kinghorn KJ, Miranda E, Page R, Curry JA, Duthie FA, Gubb DC, Lomas DA (2005) Intraneuronal Abeta, non-amyloid aggregates and neurodegeneration in a Drosophila model of Alzheimer's disease. Neuroscience 132:123-135.

Dawson GR, Seabrook GR, Zheng H, Smith DW, Graham S, O'Dowd G, Bowery BJ, Boyce S, Trumbauer ME, Chen HY, Van der Ploeg LH, Sirinathsinghji DJ (1999) Age-related cognitive deficits, impaired longterm potentiation and reduction in synaptic marker density in mice lacking the beta-amyloid precursor protein. Neuroscience 90:1-13.

Finelli A, Kelkar A, Song HJ, Yang H, Konsolaki M (2004) A model for studying Alzheimer's Abeta42-induced toxicity in Drosophila melanogaster. Mol Cell Neurosci 26:365-375.

Förstl H, Kurz A (1999) Clinical features of Alzheimer's disease. Eur Arch Psychiatry Clin Neurosci 249:288-290.

Fortini ME, Skupski MP, Boguski MS, Hariharan IK (2000) A survey of human disease gene counterparts in the Drosophila genome. J Cell Biol 150:F23-F30.

Greeve I, Kretzschmar D, Tschäpe JA, Beyn A, Brellinger C, Schweizer M, Nitsch RM, Reifegerste R (2004) Age-dependent neurodegeneration and Alzheimer-amyloid plaque formation in transgenic Drosophila. J Neurosci 24:3899-3906.

Gunawardena S, Goldstein LS (2001) Disruption of axonal transport and neuronal viability by amyloid precursor protein mutations in Drosophila. Neuron 32:389-401.

Hardy J, Selkoe DJ (2002) The amyloid hypothesis of Alzheimer's disease: progress and problems on the road to therapeutics. Science 297:353-356.

Heisenberg M (1998) What do the mushroom bodies do for the insect brain? An introduction. Learn Mem 5:1-10.

Herms J, Anliker B, Heber S, Ring S, Fuhrmann M, Kretzschmar H, Sisodia S, Müller U (2004) Cortical dysplasia resembling human type 2 lissencephaly in mice lacking all three APP family members. EMBO J 23:4106-4115

Iijima K, Liu HP, Chiang AS, Hearn SA, Konsolaki M, Zhong Y (2004) Dissecting the pathological effects of human Abeta40 and Abeta42 in Dro- sophila: a potential model for Alzheimer's disease. Proc Natl Acad Sci U S A 101:6623-6628.

Kalidas S, Smith DP (2002) Novel genomic cDNA hybrids produce effective RNA interference in adult Drosophila. Neuron 33:177-184.

Knopman DS, Parisi JE, Salviati A, Floriach-Robert M, Boeve BF, Ivnik RJ, Smith GE, Dickson DW, Johnson KA, Petersen LE, McDonald WC, Braak H, Petersen RC (2003) Neuropathology of cognitively normal elderly. J Neuropathol Exp Neurol 62:1087-1095.

LaFerla FM, Tinkle BT, Bieberich CJ, Haudenschild CC, Jay G (1995) The Alzheimer's A beta peptide induces neurodegeneration and apoptotic cell death in transgenic mice. Nat Genet 9:21-30.

Leyssen M, Ayaz D, Hébert SS, Reeve S, De Strooper B, Hassan BA (2005) Amyloid precursor protein promotes post-developmental neurite arborization in the Drosophila brain. EMBO J 24:2944-2955.

Li Y, Liu T, Peng Y, Yuan C, Guo A (2004) Specific functions of Drosophila amyloid precursor-like protein in the development of nervous system and nonneural tissues. J Neurobiol 61:343-358.

Luo L, Tully T, White K (1992) Human amyloid precursor protein ameliorates behavioral deficit of flies deleted for Appl gene. Neuron 9:595-605.

Luo LQ, Martin-Morris LE, White K (1990) Identification, secretion, and neural expression of APPL, a Drosophila protein similar to human amyloid protein precursor. J Neurosci 10:3849-3861.

Mao Z, Roman G, Zong L, Davis RL (2004) Pharmacogenetic rescue in time and space of the rutabaga memory impairment by using Gene-Switch. Proc Natl Acad Sci U S A 101:198-203.

Martin-Morris LE, White K (1990) The Drosophila transcript encoded by the beta-amyloid protein precursor-like gene is restricted to the nervous system. Development 110:185-195.

Mbebi C, González de Aguilar JL, Sée V, Dupuis L, Frossard N, Mercken L, Pradier L, Larmet Y, Loeffler JP (2005) Antibody-bound beta-amyloid precursor protein stimulates the production of tumor necrosis factoralpha and monocyte chemoattractant protein-1 by cortical neurons. Neurobiol Dis 19:129-141.

McKee AC, Kowall NW, Schumacher JS, Beal MF (1998) The neurotoxicity of amyloid beta protein in aged primates. Amyloid 5:1-9.

Merdes G, Soba P, Loewer A, Bilic MV, Beyreuther K, Paro R (2004) Interference of human and Drosophila APP and APP-like proteins with PNS development in Drosophila. EMBO J 23:4082-4095.

Müller U, Cristina N, Li ZW, Wolfer DP, Lipp HP, Rülicke T, Brandner S, Aguzzi A, Weissmann C (1994) Behavioral and anatomical deficits in mice homozygous for a modified beta-amyloid precursor protein gene. Cell 79:755-765.

Neve RL, McPhie DL, Chen Y (2000) Alzheimer's disease: a dysfunction of the amyloid precursor protein(1). Brain Res 886:54-66.

Pascual A, Préat T (2001) Localization of long-term memory within the Drosophila mushroom body. Science 294:1115-1117.

Phinney AL, Calhoun ME, Wolfer DP, Lipp HP, Zheng H, Jucker M (1999) No hippocampal neuron or synaptic bouton loss in learning-impaired aged beta-amyloid precursor protein-null mice. Neuroscience 90: 1207-1216.

Piccin A, Salameh A, Benna C, Sandrelli F, Mazzotta G, Zordan M, Rosato E, Kyriacou CP, Costa R (2001) Efficient and heritable functional knockout of an adult phenotype in Drosophila using a GAL4-driven hairpin RNA incorporating a heterologous spacer. Nucleic Acids Res 29:E55.

Reiter LT, Potocki L, Chien S, Gribskov M, Bier E (2001) A systematic analysis of human disease-associated gene sequences in Drosophila melanogaster. Genome Res 11:1114-1125.

Ring S, Weyer SW, Kilian SB, Waldron E, Pietrzik CU, Filippov MA, Herms J, Buchholz C, Eckman CB, Korte M, Wolfer DP, Müller UC (2007) The secreted beta-amyloid precursor protein ectodomain APPs alpha is sufficient to rescue the anatomical, behavioral, and electrophysiological abnormalities of APP-deficient mice. J Neurosci 27:7817-7826.

Roman G, Davis RL (2001) Molecular biology and anatomy of Drosophila olfactory associative learning. Bioessays 23:571-581.

Roman G, Endo K, Zong L, Davis RL (2001) P[Switch], a system for spatial and temporal control of gene expression in Drosophila melanogaster. Proc Natl Acad Sci U S A 98:12602-12607.

Schwaerzel M, Heisenberg M, Zars T (2002) Extinction antagonizes olfactory memory at the subcellular level. Neuron 35:951-960.

Selkoe DJ (2001) Alzheimer's disease results from the cerebral accumulation and cytotoxicity of amyloid beta-protein. J Alzheimers Dis 3:75-80. 
Selkoe DJ (2002) Alzheimer's disease is a synaptic failure. Science 298:789-791.

Senechal Y, Kelly PH, Cryan JF, Natt F, Dev KK (2007) Amyloid precursor protein knockdown by siRNA impairs spontaneous alternation in adult mice. J Neurochem 102:1928-1940.

Senechal Y, Kelly PH, Dev KK (2008) Amyloid precursor protein knockout mice show age-dependent deficits in passive avoidance learning. Behav Brain Res 186:126-132.

Sennvik K, Fastbom J, Blomberg M, Wahlund LO, Winblad B, Benedikz E (2000) Levels of alpha- and beta-secretase cleaved amyloid precursor protein in the cerebrospinal fluid of Alzheimer's disease patients. Neurosci Lett 278:169-172.

Strauss R, Heisenberg M (1993) A higher control center of locomotor behavior in the Drosophila brain. J Neurosci 13:1852-1861.

Taylor CJ, Ireland DR, Ballagh I, Bourne K, Marechal NM, Turner PR, Bilkey DK, Tate WP, Abraham WC (2008) Endogenous secreted amyloid precursor protein-alpha regulates hippocampal NMDA receptor function, long-term potentiation and spatial memory. Neurobiol Dis 31:250-260.

Torroja L, Luo L, White K (1996) APPL, the Drosophila member of the APP-family, exhibits differential trafficking and processing in CNS neurons. J Neurosci 16:4638-4650.

Torroja L, Chu H, Kotovsky I, White K (1999a) Neuronal overexpression of APPL, the Drosophila homologue of the amyloid precursor protein (APP), disrupts axonal transport. Curr Biol 9:489-492.

Torroja L, Packard M, Gorczyca M, White K, Budnik V (1999b) The Dro- sophila beta-amyloid precursor protein homolog promotes synapse differentiation at the neuromuscular junction. J Neurosci 19:7793-7803.

Tricoire H, Battisti V, Trannoy S, Lasbleiz C, Pret AM, Monnier V (2009) The steroid hormone receptor EcR finely modulates Drosophila lifespan during adulthood in a sex-specific manner. Mech Ageing Dev 130:547-552.

Tully T, Quinn WG (1985) Classical conditioning and retention in normal and mutant Drosophila melanogaster. J Comp Physiol A 157:263-277.

Tully T, Preat T, Boynton SC, Del Vecchio M (1994) Genetic dissection of consolidated memory in Drosophila. Cell 79:35-47.

Turner PR, O'Connor K, Tate WP, Abraham WC (2003) Roles of amyloid precursor protein and its fragments in regulating neural activity, plasticity and memory. Prog Neurobiol 70:1-32.

Wu JS, Luo L (2006) A protocol for dissecting Drosophila melanogaster brains for live imaging or immunostaining. Nat Protoc 1:2110-2115.

Zhao XL, Wang WA, Tan JX, Huang JK, Zhang X, Zhang BZ, Wang YH, YangCheng HY, Zhu HL, Sun XJ, Huang FD (2010) Expression of betaamyloid Induced age-dependent presynaptic and axonal changes in Drosophila. J Neurosci 30:1512-1522.

Zheng H, Koo EH (2006) The amyloid precursor protein: beyond amyloid. Mol Neurodegener 1:5.

Zheng H, Jiang M, Trumbauer ME, Sirinathsinghji DJ, Hopkins R, Smith DW, Heavens RP, Dawson GR, Boyce S, Conner MW, Stevens KA, Slunt HH, Sisoda SS, Chen HY, Van der Ploeg LH (1995) beta-Amyloid precursor protein-deficient mice show reactive gliosis and decreased locomotor activity. Cell 81:525-531. 